\title{
Serum Creatinine and Creatine Kinase as an Indicator for Gingival Wound Healing in Rabbits by Supplementation of Pomegranate Seed Extract \\ Rezan Majeed Omer (BSc, MSc, $\mathrm{PhD})^{1}$ \\ ${ }^{1}$ Department of Basic Science, College of Dentistry, Hawler Medical University, Erbil, Iraq email: rezanomer400@gmail.com
}

Received: 27 April 2021

Accepted: 20 June 2021

Published: 25 December 2021

Diyala Journal of Medicine 2021:21(2): 1-9

\begin{abstract}
Background: Pomegranate (Punica granatum) is an edible fruit that has been described as a medical and therapeutic functional food in the Middle East and the Mediterranean.

Objective: To investigate the use of serum creatinine $(\mathrm{Cr})$ level and creatine kinase $(\mathrm{CK})$ activity as indicators for gingival wound healing process rate in rabbits, supplemented on pomegranate seed extract (PSE).

Patients and Methods: A total of 45 rabbit males were used. They were divided into 3 groups; 5 rabbits as a baseline group that left without a buccal gingival wound. 20 rabbits (5 rabbits per each time interval) as a study group with buccal gingival wound with PSE supplementation, and another 20 rabbits (5 rabbits per each time interval) as a control group with gingival wound without PSE supplementation. A buccal gingival wound was created on the lower right central incisor, and the suture was removed after (7) days. Blood samples were collected for the baseline group and at time intervals; 3 hour, 1, 3, 7 days after creating the wound for both control and study groups to determine serum $\mathrm{Cr}$ and serum CK.

Results: Serum Cr and CK significantly increased in all time intervals after gingival wounds, in the control group compared with baseline values. Whereas the levels significantly increased in rabbits receiving PSE at intervals of 3 hours, 1 and 3 days after gingival wound, they returned to the baseline values, seven days after gingival wound incision.

Conclusion: Serum $\mathrm{Cr}$ and $\mathrm{CK}$ increase in the buccal gingival wound, while oral supplementation of PSE can decline them to the baseline value after a period of time, therefore these parameters can be used as indicators for gingival wound healing rate. Keywords: Punicagranatum seed extract, gingival wound healing, creatinine, creatine kinase.

DOI: https://doi:10.26505/DJM.21026020427 , CAuthors, 2021, College of Medicine, University of Diyala.

This is an open access article under the CC BY 4.0 license (http://creativecommons.org/licenses/by/4.0/)
\end{abstract}




\section{Introduction}

Oral cavity wounds can be caused by many factors, such as; surgery, trauma, and oral disease[1]. Many medicines such as; antibiotics, corticosteroids, Non-steroidal anti-inflammatory drugs (NSAIDs), and disinfectants, such as chlorhexidine have been used for speeding up the healing process rate of oral wounds[2]. However, these medicines have many side effects, such as gastrointestinal damage, discoloration, dysgeusia, and excessive sensitivity in the oral mucosa [3]. Natural products can replace these medicines [4,5]. Indeed, some plants have more healing effects and fewer side effects than these medicines [6,7].

Pomegranate (Punica granatum) is one of the oldest fruits that have been known in the Middle East [8]. All parts in PG are rich in some biologically active compounds, such as phenolics and flavonoids. Therefore, it has been described as one of nature's fruits that has been used in the medical field [9-11].

Recently, studies have shown that pomegranate can treat many cases, due to its biological activities, such as antiinflammatory, antibacterial, and antioxidant $[11,12]$. Polyphenols, such as tannins, have the primary responsibility for its treating effects of PG, especially its wound healing potency $[13,14]$. PG extracts are known to induce proliferation, collagen production, and fibroblast migration [15-17]. Prasad and Kunnaiah, 2014 reported that PG be used to treat periodontal disease and periodontium wound healing [18].

Creatinine is a non-proteinic nitrogen compound formed by a non-enzymatic dehydration reaction followed by cyclization of creatine in muscle. Creatinine is found in plasma, serum, and urine [19]. Serum creatinine is a reliable marker of muscle mass.

Creatine, the precursor of creatinine, provides energy to muscle cells [20]. Creatine is produced primarily in the kidney and liver, then can transport to muscle and brain where phosphorylated and stored as an energy source; phosphocreatine [19,20].

Creatine kinase (CK) or creatine phosphokinase (CPK) is an enzyme that catalyzes the phosphorylation of creatine $[20,21]$. Lombao et al, published that, serum CK concentration is an important marker of surgical muscle injury and is readily released during muscle injury [22]. Creatine kinase (CK) is an enzyme that is used to screen muscle injury among athletes and sports players [23]. This is primarily due to that $\mathrm{CK}$ has a relative predominance in the skeletal muscles, and is readily released during muscle injury [24]. Studies have reported that nonsurgical periodontal therapy can reduce periodontal inflammation and serum CK levels [25,26].

Therefore this study was designed to evaluate using serum creatinine $(\mathrm{Cr})$ and creatine kinase $(\mathrm{CK})$ as an indicator for buccal gingival wound healing in rabbits, by supplementation of Pomegranate seed extract.

\section{Patients and Methods}

\section{Study diagram}

This study was performed in Hawler Medical University, college of dentistry, basic science department. A total of 45 healthy rabbit males $(1.3-1.5 \mathrm{Kg})$ with the age of 6-7months were used and divided into 
3 groups; a baseline group (5 rabbits) that was left without creating an oral wound, while for the other rest animals (40 rabbits), an oral incision wound was done for them. They were divided into two groups (20 animals for each group, five rabbits for each time); study group which orally received $(100 \mathrm{mg} / \mathrm{kg} /$ day $)$ aqueous PSE, starting from 2 weeks before the surgical gingival wound and continued for 7 days after the operation, according to wound healing model. While the control group was with the same pattern of the buccal gingival wound only, it has been left without treatment. They were kept in cages, in the animal house of the college of medicine, given water, and fed with commercial food pellets.

\section{Surgical procedure}

This part was done by a specialized dentist. All the rabbits were anesthetized using $40 \mathrm{mg} / \mathrm{kg}$ ketamine and $4 \mathrm{mg} / \mathrm{kg}$ xylazine[27]. A wound was made, using a \# 11 BardParker scalpel blade, through the marginal gingival. The incision starts within the gingival sulcus, and is extended toward the tooth surface to the level of the alveolar crest. To close the wound and replace in the same previous position, a stitch with (4/0) black silk was used to suture the wound margins. The suture was removed (7) days after surgical creating a wound and suturing.

\section{Pomegranate seed Extract Preparation}

The pulps of pomegranate were pressed and the juice was removed, the seeds were taken and dried, then powdered by a grinder. $200 \mathrm{~g}$ of the powder was weighed and dissolved in $600 \mathrm{ml}$ of $70 \%$ ethyl alcohol in water, then stored at room temperature for 72 hours. The mixture was filtered, and the extract was obtained after evaporating the solvent using a rotary evaporator at $50^{\circ} \mathrm{C} .0 .1 \mathrm{~g}$ of the extract powder was suspended in $1 \mathrm{ml}$ of distilled water [28], then this suspension was orally administered to the study group.

\section{Collection of Blood Sample}

The rabbits were anesthetized with subcutaneous injection of $40 \mathrm{mg} / \mathrm{kg}$ of ketamine and $4 \mathrm{mg} / \mathrm{kg}$ of xylazine after each experiment [27], and then blood samples were obtained from the rabbits by cardiocentesis. Blood was taken for the study and control groups after creating an incision at time intervals; 3hurs, 1,3, and 7 days. All the samples were centrifuged at3000rpm for 10 minutes around $25^{\circ} \mathrm{C}$. Serum samples were stored at $-20{ }^{\circ} \mathrm{C}$ until the chemical analysis. Serum Creatinine was determined by a specific Biolabo company kit [29,30]. While Serum CK activity was determined using a specific Biolabo company kit depending on a colorimetric method [31,32].

\section{Statistical analysis}

Version 22 was used for the data analysis. The data of this study was described by the mean with the standard deviation $\pm(\mathrm{SD})$. A ttest was used for comparing two means. Pvalue of 0.05 or less was regarded as a statistically significant difference.

\section{Results}

The serum $\mathrm{Cr}$ and $\mathrm{CK}$ activities in the baseline group and Control group are shown in table (3-1). From the results, a significant increase in serum $\mathrm{Cr}$ levels and serum $\mathrm{CK}$ activities have been found, three hours(1.05 $\pm 0.16,187.75 \pm 9.17$ respectively), one day $(1,78 \pm 0.18, \quad 244.34 \pm 12.61$ respectively) and three days $(2.25 \pm 0.23$, $273 \pm 13.35$ respectively) after gingival wound 
incision comparing with the baseline values. Then these increased values declined 7 days after incision (1.55 \pm 0.21 and 202.56 \pm 11.72 respectively), but still significantly higher than its baseline value $(0.71 \pm 0.14$, $165.22 \pm 8.68$ respectively).

The serum $\mathrm{Cr}$ levels and serum $\mathrm{CK}$ activities in rabbits of the study group at time intervals after creating gingival incision are shown in table (3-2). The results indicated a ranging from 8-77 years, the median age was 45.5 years, male: female ratio was 1.07:1.

Table (1): Serum Cr levels and CK activities (mean \pm SD) in rabbits receiving distilled water (Control group) before (baseline) and after time intervals of creating gingival incision wound

\begin{tabular}{|c|c|c|c|c|}
\hline Parameters & \multicolumn{2}{|c|}{ Time intervals } & Mean \pm SD & $P-$ \\
\hline \multirow{5}{*}{$\begin{array}{l}\text { Serum Cr. } \\
(\mathrm{mg} / \mathrm{dL})\end{array}$} & Before incision & Baseline & $0.71 \pm 0.14$ & \\
\hline & \multirow{4}{*}{ After incision } & $3 \mathrm{H}$ & $1.05 \pm 0.16$ & $\mathrm{~S}$ \\
\hline & & $1 \mathrm{D}$ & $1.78 \pm 0.18$ & $\mathrm{~S}$ \\
\hline & & $3 \mathrm{D}$ & $2.25 \pm 0.23$ & $\bar{S}$ \\
\hline & & $7 \mathrm{D}$ & $1.55 \pm 0.21$ & $\overline{\mathrm{S}}$ \\
\hline \multirow{5}{*}{$\begin{array}{l}\text { Serum CK } \\
(\mathrm{IU} / \mathrm{L})\end{array}$} & Before incision & Baseline & $165.22 \pm 8.68$ & \\
\hline & \multirow{4}{*}{ After incision } & $3 \mathrm{H}$ & $187.75 \pm 9.17$ & S \\
\hline & & $1 \mathrm{D}$ & $244.34 \pm 12.61$ & $\mathrm{~S}$ \\
\hline & & $3 \mathrm{D}$ & $273 \pm 13.35$ & S \\
\hline & & $7 \mathrm{D}$ & $202.56 \pm 11.72$ & $\bar{S}$ \\
\hline
\end{tabular}

*S: significant, H: hour, D:day

Table (2): Serum Cr levels and CK activities (mean \pm SD) in baseline group and study group (rabbits receiving pomegranate seed extract at time intervals after creating a gingival incision wound

\begin{tabular}{|c|c|c|c|c|}
\hline Parameters & \multicolumn{2}{|c|}{ Time intervals } & \multirow{2}{*}{$\begin{array}{l}\text { Mean } \pm \text { SD } \\
0.71 \pm 0.14 \\
\end{array}$} & \multirow{2}{*}{$\begin{array}{c}P- \\
\text { value }\end{array}$} \\
\hline \multirow{5}{*}{$\begin{array}{l}\text { Serum } \\
\text { Cr. } \\
\text { (mg/dL) }\end{array}$} & Before incision & baseline & & \\
\hline & \multirow{4}{*}{ After incision } & $3 \mathrm{H}$ & $0.10 \pm 0.13$ & $\mathrm{~S}$ \\
\hline & & $1 \mathrm{DD}$ & $1.65 \pm 0.20$ & $\overline{\mathrm{S}}$ \\
\hline & & $3 \mathrm{D}$ & $1.33 \pm 0.18$ & $\mathrm{~S}$ \\
\hline & & $7 \mathrm{D}$ & $0.78 \pm 0.15$ & $\mathrm{NS}$ \\
\hline \multirow{5}{*}{$\begin{array}{r}\text { Serum } \\
\mathrm{CK} \\
(\mathrm{IU} / \mathrm{L}))\end{array}$} & Before incision & baseline & $165.22 \pm 8.68$ & \\
\hline & \multirow{4}{*}{ After incision } & $3 \mathrm{H}$ & $183 \pm 8.44$ & $\mathrm{~S}$ \\
\hline & & $1 \mathrm{D}$ & $216 \pm 11.39$ & $\bar{S}$ \\
\hline & & $3 \mathrm{D}$ & $190.37 \pm 12.35$ & S \\
\hline & & $7 \mathrm{7D}$ & $176.50 \pm 10.47$ & NS \\
\hline
\end{tabular}

* NS: non-significant, S: significant, H: hour, D: day 


\section{Discussion}

The results showed a significant increase in serum $\mathrm{Cr}$ level and CK activity after gingival wound incision, but the values in rabbits receiving PSE (study group) declined seven days after suture removal, and they returned close to their baseline values. This decline in the serum Cr value and CK activity may be related to the effect of the PSE which contains antioxidant and anti-inflammatory agents that reduce the formation of nitric oxide and Prostaglandin E2 (PGE2) [33,34]. Therefore gingival and periodontal tissue damage will decrease, and $\mathrm{Cr}$ and $\mathrm{CK}$ release into the blood also will decrease [34].

Reactive oxygen species (ROS) damage cells and tissues; hence they are bad for wound healing and they peroxidize lipids, inactivate enzymes, and break DNA down [35].

Pomegranate parts contain powerful antioxidants shown to improve human health. The antioxidant and anti-inflammatory properties of pomegranate fruits, which can accelerate the wound healing process, can be attributed partly to vitamin $\mathrm{C}$ and vitamin $\mathrm{E}$ that pomegranate contains. Besides, tannins and polyphenols like ellagic acid, gallic acid, and coumaric acid are found in pomegranate seeds [36-39]. The presence of polyphenols (such as gallic acid) and quercetin in pomegranate can improve muscular strength and recovery [40-42].Researchers investigated the effects of oral administration of pomegranate peel (PPE) extract on the healing of surgically induced full thickness of the gingival wound. Their results showed that oral administration of PPE can stimulate healing properties in gingival wounds, in the rabbit model by controlling free radicals and lipid peroxidation [43].

The observation of the study was in the same line as that of Chraf et al, who concluded that Pomegranate juice seems to have significant effects on serum creatinine, muscle damage parameters (such as creatine kinase), and C-reactive protein [44]. Our finding is agreement with Ammar et al, who found that both serum $\mathrm{CK}$ and Lactate dehydrogenase (LDH); the biomarkers for muscle damage during exercise, were reduced after pomegranate supplementation [42].

The result of the present study is in the same line as the result of Alshail et al, who found that increases in the periodontal tissues are associated with increased serum CK levels. Thus, they concluded that the increase in serum $\mathrm{CK}$ level might indicate a compromised oral health status [45]. The results are in the same direction as Cintra et al results, who found that increase in serum creatinine is related to gingival damage due to oral infections [46]. Also, the result of the study is in agreement with Yoshihara et al finding, who observed relation of gingival and periodontium tissue damage with creatinine level [47].

\section{Conclusions}

From the results, it can be concluded that gingival wound healing can be accelerated by PSE supplementation, and this phenomenon was in line with the reduction in serum $\mathrm{Cr}$ and serum CK activity, thus these parameters can be used as indicators for gingival wound healing rate. 


\section{Recommendations}

Testing the other parts of pomegranate fruit extracts such as the peel for its potency in speeding up the rate of gingival wound healing and the use of both serum $\mathrm{Cr}$ and $\mathrm{CK}$ as indicators in this case.

Source of funding: This research was funded by ourselves and these is no other funding cover this study or manuscript preparation and publication.

Ethical clearance: The study was approved by the academic ethical committee, College of Dentistry, Hawler Medical University.

\section{Conflict of interest: Nill}

\section{References}

[1]Socransky SS; Ha_ajee AD. Periodontal microbial ecology. Periodontology 2005; 38: 135-187.https://doi: $10.1111 / \mathrm{j} .1600-$ 0757.2005.00107.x

[2]Cleland Jr. WP. Opportunities and obstacles in veterinary dental drug delivery. Adv. Drug Deliv. Rev. 2001;50: 261-275. https://doi: 10.1016/s0169-409x(01)00161-2. [3]Gjermo P. Chlorhexidine and related compounds. J. Dent. Res. 1989;68: 16021608.

https://doi.org/10.1177/00220345940730031 401

[4]Saraf, S. Formulating moisturizers using natural raw materials. In Treatment of Dry Skin Syndrome, 1st ed. Lodén, M., Maibach, H.I., Eds.; Springer: Berlin, Germany; 2020, pp. 379-397.

https://doi.org/10.3390/biom10091234

[5]Ghosh, PK, Gaba A. Phyto-extracts in wound healing. J. Pharm. Pharm. Sci. 2013; 16: $760-820$.

https://doi.org/10.18433/J3831V
[6]Davis RH, Maro NP. Aloe vera and gibberellin. Anti-inflammatory activity in diabetes. J. Am. Podiatr. Med. Assoc. 1989;79: 24-26. https:// doi: 10.7547/87507315-79-1-24

[7]Biswas TK, Mukherjee B. Plant medicines of Indian origin for wound healing activity: A review. Int. J. Low. Extrem.Wounds.2003; 2:25-39.

https://doi: 10.1177/1534734603002001006

[8]Chandra R, Babu KD, Jadhav VT, Jaime A, Silva TD. Origin, history and domestication of pomegranate. Fruit, Veg. Cereal Sci. Biotech.2010; 2: 1-6.

http://scholar.google.com > citations.

[9]Rahimi HR, Arastoo M, Ostad SN. A comprehen-sive review of Punica granatum (pomegranate) prop-erties in toxicological, pharmacological, cellular and molecular biology researches. Iranian journal of pharmaceutical research: IJPR, 2012; 11(2):385.https://www.ncbi.nlm.nih.gov > articles > PMC3832175 [10]Al-Shaaibi SN, Waly MI, Al-Subhi L, Tageldin MH, Al-Balushi NM, Rahman MS. Ameliorative effects of pomegranate peel extract against dietary-induced nonalcoholic fatty liver in rats. Preventive nutrition and food science. 2016;21(1):14. https://doi: 10.3746/pnf.2016.21.1.14.

[11]Moneim AE, Dkhil MA, Al-Quraishy S. Studies on the effect of pomegranate (Punica granatum) juice and peel on liver and kidney in adult malemrats. Journal of Medicinal Plants Research. 2011; 5(20):50838.https://doi.org/10.5897/JMPR.9001157 [12]Bashir MA, Elshawesh MA, Alatresh OK, Elgenaid AR. Protective effect of pomegranate peel extract on dietary induced non-alcoholic fatty liver disease, MMSJ, 
2020;4

(2):1-6.

http://www.misuratau.edu.ly/journal/mmsj/.

[13] Fleck A, Cabral PF, Vieira FF, Pinheiro DA, Pereira CR, SantosWC. et al. Punica granatum L. hydrogel for wound care treatment: From case study to phytomedicine standardization. Molecules. 2016;21:1059. https:// doi: 10.3390/molecules21081059. [14] Tang J, Li B, Hong S, Liu C, Min J, Hu, M, et al. Hong, Punicalagin suppresses the proliferation and invasion of cervical cancer cells through inhibition of the - -catenin pathway. Mol. Med. Rep.2017;16:14391444. https://doi: 10.3892/mmr.2017.6687. [15]Nema N, Arjariya S, Bairagi S, Jha M, Kharya MD. In vivo topical wound healing activity of Punica granatum peel extracts on rats.AJPCT. 2013;1:195-200. https://doi: 10.4103/0972-124X.138678

[16] Singer AJ, Clark RA. Cutaneous wound healing. N Eng J Med.1999; 341: 738-46. https://doi:10.1056/NEJM199909023411006. [17]Yan H, Peng KJ, Wang QL, Gu ZY, Lu YQ, Zhao J, et al. Effect of pomegranate peel. polyphenol gel on cutaneous wound healing in alloxan- induced diabetic rats. Chin Med J (Engl) 2013; 126:1700-6. https://www.revmedvet.com

RMV164_400_408

[18]Prasad D, Kunnaiah R. Punica granatum: A review on its potential role in treating periodontal disease. J Indian Soc Periodonto 1 Jul-Aug. 2014; 18(4): 428-432. https:/doi: 10.4103/0972-124X.138678 [19]Wei F, Cheng S, Korin Y, Reed EF, Gjertson D, Ho CM, et al. Serum creatinine detection by a conductingpolymer-based electrochemi-cal sensor to identify allograft dysfunction. Anal Chem.
2012,84(18);7933-7.

https://doi: $10.1021 / \mathrm{ac} 3016888$

[20]Schott HC, Waldridge B, Bayly W. Disorders of the Urinary System, Equine Internal Medicine $4^{\text {th }}$ Ed. Chapter 14. In: Reed SM, Bayly WM, Sellon DC, editors. 2020, p.888-990. https://veteriankey.com , disorders-of-the-urinary-system

[21]Tietiz N W. Tietz Textbook of Clinical Chemistry, 3rd Ed. Burtis C. A. Ashwood E. R. and Saunders W. B, 1999, p.1241-1245. https://www.amazon.com > Tietz-TextbookClinical-Ch.

[22]Lombao I D, Bagó G J, Vilor R T. Validity of creatine kinase as an indicator of muscle injury in spine surgery and its relation with postoperative pain. Acta Orthop Belg 2014;80:545-50.

https://pubmed.ncbi.nlm.nih.gov >

[23]Abián P, Coso JD, Salinero JJ, GalloSalazar C, Areces F, Ruiz-Vicente D, et al. Muscle damage produced during a simulated badminton match in competitive male players. Res Sports Med 2015:1-14. https://doi:10.1080/15438627.2015.1076416] [24]Brancaccio P, Limongelli FM, Maffulli $\mathrm{N}$. Monitoring of serum enzymes in sport. $\mathrm{Br}$ J Sports Med, 2006; 40: 96-7.

https://doi: 10.1136/bjsm.2005.020719

[25] Javed F, Ahmed HB, Mehmood A, Bain C, Romanos GE. Effect of nonsurgical periodontal therapy (with or without oral doxycycline delivery) on glycemic status and clinical periodontal parameters in patients with prediabetes: A short-term longitudinal randomized case-control study. Clin Oral Investig. 2014;18: 1963-8. https://doi: 10.1007/s00784-014-1185-6. 
[26]Toker H, Akpinar A, Aydin H, Poyraz O. Influence of smoking on Interleukin-1-beta level, oxidant status and antioxidant status in gingival crevicular fluid from chronic periodontitis patients before and after periodontal treatment. J Periodontal Res.2012; 47:572-7. https://doi: 10.1111/j.1600-0765.2012.01468.x.

[27] Hedenqvist P. Anaesthesia and analgesia for surgery in rabbits and rats: A comparesion of the effects of different compounds. PhD. Thesis submitted to the Karolinska Institutent, Stckholm Sweden.2008.https://openarchive.ki.se > bitstream > handle > thesis [28]Rouhi SZT, Sarker MR, Rahmat A, Alkahtani SA, and Othman F. The effect of fresh pomegranate juice versus pomegranate seed powder on metabolic indices, lipid profile, inflammatory biomarkers, and the histopathology of pancreatic islets of Langerhans in streptozotocin-nicotinamide induced type 2 diabetic Sprague- Dawley rats. BMC Complement Altern Med. 2017;17(1):156. https://doi: 10.1186/s12906017-1667-6.

[29]Fabiny DL. Ertingshausen B: Automated reaction rate method for determination of serum creatinine with the CentrifiChem. Clin Chern. 1971; 17(8):696-700. https://doi: $10.1177 / 000456327701400161$.

[30]Labbé D Vassault A, Cherruau B, Baltassat $\mathrm{P}$, Bonète $\mathrm{R}$, Carroger $\mathrm{G}$, et al Method selected for the determination of creatinine in plasma or serum. Choice of optimal conditions of measurement. Ann Biol Clin. 1996;54(8-9):285-98. https://pubmed.ncbi.nlm.nih.gov > [31]Oliver IT. A spectrophotometric method for the determination of creative phosphokinase and myokinase. The Biochemical Journal. 1955; 61(1):116-122. https://doi: 10.1042/bj0610116

[32]Rosalki S B An improved procedure for serum creatine phosphokinase determination. J Lab Clin Med. 1967; 69(4):696-705. https://europepmc.org > abstract > med [33]LeeCJ, Chen LG, Liang WL, Wang CC. Anti-inflammatory effects of Punica granatum Linne invitro and in vivo. Food Chem.2010; 118: 315-322. https://dol:10.1016/j.foodchem.2009.04.123 [34]Waghulde S, Bhopi S, Ghude T, Gotarane R, Kale M. Comparative AntiInflammatory Activity of Aril Extracts of Punica granatum Fruits.Proceedings, 2019; 9: 66; https://doi: 10.3390/ecsoc-2205783.

[35]Aliyev E, Sakallığlu U, Eren Z, Açikgöz G. The effect of polylactide membranes on the levels of reactive oxygen species in periodontal flaps during wound healing. Biomaterials, 2004; 25(19):46334637.

https://doi:10.1016/j.biomaterials.2003.12.00 4.

[36]Artik, N, Murakami H, Mori T. Determination of phenolic compounds in pomegranate juice by using HPLC. Fruit Processing, 1998; 8: 492-499. https://doi.org/10.1016/j.arabjc.2013.10.011 [37]Aviram M, Dornfeld L, Kaplan M, Coleman R, Gaitini D, Nitecki S, et al. Pomegranate juice flavonoids inhibit lowdensity lipoprotein oxidation and cardiovascular diseases: studies in atherosclerotic mice and in humans. Drugs Exp Clin Res. 2002;28 (2-3):49-62. https://europepmc.org > reload=0 PMID: 12224378. 
[38]Özkan M, Kırca A, Cemeroğlu B. Effects of hydrogen peroxide on the stability of ascorbic acid during storage in various fruit juices. Food chemistry,2004; 88

(4):591597.

https://doi:10.1016/j.foodchem.2004.02.011 [39] Asadi M S, Mirghazanfari S M, Dadpay M, Nassireslami E. Evaluation of wound healing activities of pomegranate (Punica granatum - Lythraceae) peel and pulp. J Res Med Dent Sci, 2018; 6(3): 230-236. https://doi:10.24896/jrmds.20186336 [40]Torregrosa-García A, Ávila-Gandía V, Luque-Rubia AJ, Abellán-Ruiz MS, QuerolCalderón $\mathrm{M}$, and López-Román FJ. Pomegranate Extract Improves Maximal Performance of Trained Cyclists after an Exhausting Endurance Trial: A Randomised Controlled Trial. Nutrients. 2019;11(4): 721. https://doi: 10.3390/nu11040721.

[41]Malaguti M, Angeloni C, Hrelia S. Polyphenols in exercise performance and prevention of exercise-induced muscle damage. Oxid Med Cell Longev.;2013:2013:825928.

https://doi: 10.1155/2013/825928

[42]Ammar A, Turki M, Chtourou H, Hammouda O, Trabelsi K, Kallel C et al. Pomegranate supplementation accelerates recovery of muscle damage and soreness and inflammatory markers after a weightlifting training session. PLoS One. 2016; 11(10):e0160305. https://doi: 10.171/journal.pone.0160305 [43]Smith P.C, Cáceres M, Martínez C, Oyarzún A, Martinez J.Gingival wound healing: an essential response disturbed by aging? J Dent Res. Mar. 2015; 94(3): 395402. https://doi: $10.1177 / 0022034514563750$
[44]Achraf A, Hamdi C, Turki M, Abdel Karim O, Ayadi F , Hoekelmann A, et al. Natural pomegranate juice reduces inflammation, muscle damage and increase platelets blood levels in active healthy Tunisian aged men, Alex. J.Med2018; 54(1):1-4.

https://doi:

10.1016/j.ajme.2017.03.005

[45]Alshail F, AljoharA, Alshehri M. Periodontal status and serum creatine kinase levels among young soccer players: A preliminary report, Nigerian Journal of Clinical Practice. 2015;19 (5):655-658. https://doi: 10.4103/1119-3077.188708

[46]Cintra LT, Facundo AC , Valentim D , Prieto AK, Silva CO, Sumida DH, et al. Effect of Oral Infections on Serum Creatinine Levels in Diabetic Rats. Int J Diabetol Vasc Dis Res. 2013;1(3):19-23. https://doi:10.19070/2328-353X-1300026

[47]Yoshihara A, Hayashi Y, Miyazaki H.Relationships among bone turnover, renal function and periodontal disease in elderly Japanese. J Periodonta. Res.2011; 46(4): 491-496. https://doi.org/10.1111/j.1600-

0765.2011.01365.x 